This chapter argues that postsecondary competencies and awards have become the threshold requirement for middle-class earnings and status.

\title{
Help Wanted: Postsecondary Education and Training Required
}

\author{
Anthony P. Carnevale, Jeff Strohl, Nicole Smith
}

For most of the twentieth century, high school was enough for a shot at middle-class status and wages. Today no one goes anywhere in the American job market without some postsecondary education or training.

\section{The increasing importance of education and training beyond high school in allocating economic opportunity results from broad social and economic trends.}

These are the major trends: the rise of the global knowledge economy; the slow and painful demise of the American blue-collar economy in which workers, mostly white males, earned good wages with a high school education or less; welfare reform and the emergence of "work first" as the guiding principle in social policy; and a society where men, women, and youth are fully mobilized at work.

The notion that some kind of postsecondary education and training has become the threshold requirement for middle-class earnings and status has not been lost on the American public. More than two-thirds of Americans go on to postsecondary education or training after high school, although only 34 percent of students in eighth grade will later go on to get a degree from a two-year or four-year school. Access to college has become the essential goal for $\mathrm{K}-12$ education. Middle-class employability is now the penultimate standard for K-16 educational adequacy (authors' calculations using data from National Center for Education Statistics, 1988, and CPS Utilities, 2007). 
Data from the Current Population Survey (CPS) show that between 1973 and 2007, the share of prime-age workers, between thirty and fiftynine years old, with at least some college increased from 28 percent to almost 60 percent. Over that same period, the share with a B.A. or better doubled from 16 percent to 32 percent, while the share of subbaccalaureate attainment more than doubled from 12 percent to 28 percent. Associate degree holders currently comprise a third of the subbaccalaureate workforce while those with some college but no A.A. or B.A. comprise roughly twothirds (authors' calculations from data in CPS, 2007). The rising tide in career-related human capital development has come in every venue and shows that the full array of degrees, certificates, and other awards is not captured by the traditional degree categories.

One of the more striking trends in these data is the steady increase in female participation over males below the doctoral level. Average earnings increase progressively with the standard hierarchy of certificates and degrees. The difference between male and female wage hierarchies is one possible explanation for the relative increase in female participation in postsecondary education; earning less at each degree level, women need more postsecondary education to make male wages.

\section{More education is generally better than less, but the curriculum and the occupational focus are sometimes more important.}

Until recently the economic value of education has largely been a matter of degrees: whoever had the most education and the highest degree level got the best jobs. As education connects more closely with the economy and the share of Americans going on to postsecondary education, however, these historical relationships between degree attainment and earnings are changing. Now it matters not only if you go and graduate; what you take, where you go, and what occupation or industry you enter into matter more and more. The earnings differences among people with different degree levels are growing. For instance, 22 percent of those with an occupational or vocational A.A. earn more than the median earnings of those with a B.A. and 14 percent earn more than the median earnings of people with graduate degrees. In turn, 25 percent of those with a B.A. earn less than those with an A.A. degree, and 23 percent earn less than those with a license or certificate but not an A.A. Not only is the overlap between people with different degrees growing, but so are the earnings differences among people with the same degree.

\section{The strength of the relationship between postsecondary education and opportunity has increased in both the real economy and American politics.}

Americans welcome the increasing reliance on postsecondary education as the arbiter of economic opportunity because, in theory, it allows us to expand merit-based opportunity without surrendering individual responsibility. After all, we each have to do our own homework to make the grades 
and do well on the tests that get us into college and in line for good jobs. Education-based opportunity complements our other key preferences for an open economy and a limited government. Education has become the nation's preferred third way between the economic instability that comes with runaway global markets and the individual dependency that Americans associate with the welfare state.

The growing economic power of postsecondary education allows us to anchor economic opportunity in individual talent and effort without government interference in the economy or the labor market.

\section{With no substantial terminal vocational alternative in high school, "College for All" and its homely country cousin, "Postsecondary Edu- cation and Training for All," resonate with our recent experience on the ground in the real economy.}

Most new jobs that require postsecondary preparation have been created in white-collar office jobs, education and health care jobs, and hightech jobs-the signature occupations and industries in the often-cited "new knowledge economy."

The increasing reliance on postsecondary education as the arbiter of opportunity is a direct result of the rise of the postindustrial service economy and the increasing share of office workers. The share of white-collar office jobs, the workforce in the new service economy, has risen from 30 to 40 percent since 1973. In 1973, only 38 percent of office workers had some kind of postsecondary education. Today 69 percent of office workers have some postsecondary education: almost 40 percent have at least a bachelor's degree, 10 percent have associate degrees, and more than 20 percent have some college but no degree, making office work one of the most highly educated job sectors.

The health care and education sectors continue to grow as developing and maintaining human capital become more important in the knowledge economy. Since the 1970s, education and health care jobs have increased from 10 percent to almost 20 percent of all jobs. The share of education and health care jobs with at least some college increased from fewer than half in the 1970s to more than 75 percent today, with more than 52 percent with a bachelor's or graduate degree, 11 percent with an associate degree, and 12 percent with some college but no degree.

The share of technology jobs has doubled from roughly 4 to 8 percent of all jobs. In 1973, 63 percent of technology workers had at least some college, while 86 percent now have postsecondary education. More than half have at least a bachelor's degree, 16 percent have an associate degree, and almost 20 percent have some college but no degree.

Factory jobs are shrinking both proportionally and in absolute numbers. Since 1960, the factory share has fallen from 32 to 17 percent. New technology and high-performance work processes combine to enable manufacturers to produce more goods while using fewer but more highly skilled 
workers. Since 1960, the United States has increased real manufacturing output by nearly 3 percent annually without increasing the number of production workers. In 1973, only 12 percent of workers on the factory floor had any college, but that percentage has now increased to more than 36 percent. Roughly 6 percent have a bachelor's degree or better, 8 percent have an associate degree, and 17 percent have some college but no degree.

Like factory jobs, natural resource jobs, including farming, fishing, forestry, and mining, are in decline both as a share of the economy and in actual jobs. Natural resource jobs accounted for about 5 percent of all jobs in 1959. These jobs had declined by more than two-thirds and now account for only about 1.5 percent of all jobs in the economy. In 1973, two-thirds of these workers were high school dropouts; now workers with at least some college hold 31 percent of these jobs.

Low-wage service jobs are a mixed bag of transitional jobs and career jobs. The share of low-wage services jobs has not grown since the 1950s, remaining at about one-fifth, or about 28 million, of the available jobs. We tend to overestimate the importance of low-wage service jobs in the dynamic that links learning and careers. Many of the people in these jobs are young, sometimes in school, in transition to something better, or are older workers in transition to retirement. This is especially true for workers below the age of twenty-five who will likely move on to better jobs when they complete their education or training.

\section{The increase in the wage premium for employees with postsecondary education relative to high school graduates is the most significant sig- nal that the economy is demanding more postsecondary-level workers.}

During the 1960s and 1970s, the wage premium for postsecondary education fell, but throughout the 1980s and 1990s, the wage premium for workers with postsecondary education began to climb again. CPS data show that the wage advantage for postsecondary education has generally held up and even improved in spite of a huge increase in the supply of collegeeducated workers.

Between 1983 and 2007, the number of prime-age workers with some college but no degree increased by 11 million people (from 6 to 17 million workers), rising from 9 percent to 17 percent of the workforce. Their average wages increased from $\$ 22,571$ to $\$ 29,070$ in 2007 dollars. Between 1983 and 2007 the number of prime-age workers with associate degrees increased from 7.6 to 9.1 million workers. Their real wages increased from $\$ 25,000$ to $\$ 33,000$. And over the same period, the number of those with a bachelor's degree increased from 10 to 20 million, and in spite of the increased supply, their average real wages increased from $\$ 33,000$ to $\$ 48,000$. And the number of prime-age workers with a master's degree or higher increased from 4 to 10 million. Their average real wages increased from $\$ 45,000$ to $\$ 72,000$.

Since the 1970s the share of workers with at least some college tripled, while their wage advantages over workers with high school educations 
almost doubled over the same period. This development is remarkable: usually when the supply of anything increases, its price goes down. Since the 1990s, employed workers with at least some college increased by 32 percent or 18.4 million new workers, divided equally among workers with a bachelor's degree or higher and subbaccalaureate college workers.

\section{Postsecondary education and training have become the nation's work- force qualification and development system outside the workplace by both design and default.}

Society has flirted with an alternative second-chance workplace education and training system dedicated to workforce development and retraining for economic adjustment, but all that has been learned from the second-chance system is that what counts is the first chance at $\mathrm{K}-16$ education. For now, the second-chance system has been all but abandoned. Federal funding for workplace training, in real 2003 dollars, declined from $\$ 27$ billion in the last Carter budget to about $\$ 3$ billion in the 2007 Bush budget.

The emergence of postsecondary institutions as the primary workforce development institutions outside the labor market is evident in the gradual but relentless movement toward vocational, occupational, and professional education in postsecondary programs. For example, of the almost 1.4 million bachelor's degrees awarded in 2004, 42,106 were conferred in the liberal arts and sciences, general studies, and humanities. More than 80 percent of master's degrees and 60 percent of doctorates are awarded in nonacademic fields. The same pattern is reinforced in the expansion in applied associate degrees, certificates, certifications, and customized training. Of the 665,301 associate degrees awarded in 2004, 227,650 were conferred in the liberal arts and sciences, general studies, and humanities, and only 801 were conferred in mathematics.

If the immediate past is any guide, the future promises more of the same.

Projections that we prepared for the U.S. Senate Committee on Health, Education, Labor, and Pensions using both U.S. Census and Bureau of Labor Statistics data show that between 2002 and 2012, there will be 24 million new jobs for workers with associate, bachelor's, and graduate degrees, a 30 percent increase.

Will we be able to meet the future demand for college workers if we rely on America's own college workforce? Not easily. Baby boom retirements should create a steady stream of replacement openings for collegeeducated workers; by 2020, for example, there will be 40 million college-educated baby boomers between the ages of fifty-five and seventyfive. Census data show that the United States is not producing collegeeducated workers fast enough to replace retiring baby boomers. Between 1980 and 2000, we increased the share of workers with at least some college by a hefty 20 percent. At current rates of college enrollment, the share 
of workers with at least some college will increase by only 3 percent between 2000 and 2020.

To counter this projected shortage, competition for college workers could increase wages and encourage college enrollment and graduation. But rising college wages over the past thirty years have not resulted in supply catching up with demand. In the future, the increasing size of the global college workforce could hold college wages down in the United States, blunting incentive effects, as it already has in engineering and information technology. The United States could move toward a skill-based immigration strategy to import more college workers.

The United States could also delay retirement for college-educated baby boomers by squeezing access to social security and health care, but political opposition would be significant. Our estimates indicate that delaying retirements by delaying government benefits will mostly affect workers with no postsecondary education or training, who are most dependent on government retirement benefits. And although older workers are more experienced, those with postsecondary preparation and a lifetime of wage progress are also expensive relative to younger workers in America and the rest of the world.

It does seem intuitively sensible that workers will want to work longer as life expectancy rises. Baby boomers are indeed working longer, but actuaries have no evidence thus far that the change in retirement behavior will compensate for the sheer volume of retirees and the flattening of educational attainment among younger cohorts.

\section{The wild card in the economic future role of college education as the arbiter of economic opportunity is the global economy.}

In the 1970s and 1980s, low-skill, low-wage jobs went overseas, but beginning in the late 1990s, 70 percent of offshored jobs have required at least some college. With the addition of Brazil, Russia, India, and China, the size of the earth's capitalist workforce has doubled, reducing the U.S. share of the world's college-level workers from about 30 to 15 percent. And foreign college workers will be a lot cheaper than American workers for decades to come.

So far, offshoring has been a trickle: a few hundred thousand jobs a year at most. Moreover, an authoritative McKinsey study (2005) estimates that only about 3 to 5 million people in Brazil, Russia, India, and China have the appropriate postsecondary skills and English-speaking abilities necessary to substitute for American workers with postsecondary education.

Although the actual level of offshoring has been relatively low, the potential for it is much larger. Our preliminary analysis demonstrates three levels of potential offshoring risk in the current American workforce. Using our criteria, we find that there appear to be about 8 million jobs where risk is as high as 80 percent, about 22 million jobs where risk is roughly 50 percent, and as many as 40 million American jobs that are theoretically vulnerable if we include risk levels below 50 percent. 
The potential for offshoring is not just about losing the postsecondary jobs in the United States; it's also about capital flows and their effect on future jobs. The balance of capital flows in and out of the United States can leverage an invisible offshoring of college jobs if America loses its magnetic pull on global capital. The ability to attract and retain financial capital and focus investments on high-value-added jobs that generally require at least some college is just as important as keeping existing college jobs.

While the risks of offshoring can be scary, static analysis of offshoring risk tends to overstate the risks and understate the opportunities, especially in the United States, the world's most dynamic labor market.

The United States creates and destroys jobs faster than any other economy in the world. Moreover, the central tendency in this process of creative destruction is to increase skill and earnings levels. According to Vollman's analysis of wage record data (personal communication, July 2008), every three months, nearly 14 million workers will be hired and 13.6 million will leave their current jobs. More than half of those actions will happen because a new job was created or a job disappeared. The rest will be because someone was moving between jobs or on or off unemployment. We offer three additional observations to demonstrate the dynamism of the American economy:

- Every year, more than a third of the entire U.S. labor force changes jobs.

- Every year, more than 30 million Americans are working in jobs that did not exist in the previous quarter.

- Many of the occupations workers have today did not exist five years ago.

We need to keep this constant churning in mind while considering the likely impact of offshoring and other disruptive forces in American labor markets.

If we want to increase the number of students who enroll and graduate from postsecondary institutions, the "low-hanging fruit" are the more than half a million college-qualified students from working families who are lost along the way in high school.

There are more than half a million students, mostly from working class and low-income families, who complete high school in the top half of their classes but never earn an associate, bachelor's, or a graduate degree within eight years of high school graduation. Among these college-qualified students who do not attend college or do not graduate within eight years of high school graduation:

Twenty-three percent, or 129,000 of the 559,000 top students, come from families in the top income quartile $(\$ 83,001$ and above in 2005 , with a median of $\$ 145,000)$. 
Thirty-three percent, or 185,000 of the 559,000 top students, come from families in the second income quartile from the top $(\$ 50,280$ to $\$ 83,000$ in 2005 , with a median of $\$ 65,512$ ).

Twenty-five percent, or 140,000 of the 559,000 top students, come from families in the third income quartile from the top $(\$ 26,730$ to $\$ 50,279$ in 2005 , with a median of $\$ 38,306$ ).

Nineteen percent, or 106,000 of the 559,000 top students, come from families in the bottom income quartile $(\$ 26,729$ or less in 2005 , with a median of $\$ 15,000)$.

As many as 11 million adults and out-of-school youth could benefit from postsecondary education and training, especially in community colleges, but they are unlikely to be served.

According to an analysis of the National Adult Literacy Survey (National Center for Education Statistics, 1992), roughly half of low-income workers and out-of-school youth have literacy levels that qualify them for collegelevel work. The share of qualified prisoners is roughly 30 percent, and the share of dislocated workers qualified for postsecondary education or training could be as high as 60 percent (Kirsch and Jungeblut, 1992; Kirsch, Jungeblut, Jenkins, and Kolstad, 1993). If trained, they could add more than $\$ 120$ billion to the national wealth. And in the case of prisoners, recidivism could be reduced by as much as 29 percent (Steurer, Smith, and Tracy, 2001).

\section{While the benefits of providing postsecondary education and training are powerful and growing, so are the barriers to access, especially for nontraditional students.}

The funding barriers are the most daunting, especially for community colleges whose missions keep expanding and whose revenue base keeps contracting relative to other public and private providers.

Part of the community college funding problem results from the fact that the postsecondary funding system is not nearly as flexible as the community colleges themselves. Initially founded as junior colleges, these schools became community-based teaching institutions and took on an increasingly occupational role in local labor markets for place-bound students of all ages. The community college gradually outgrew its marginalized status as a "junior" to four-year institutions. Its emergence as an alternative to the traditional fouryear college came with an implicit rebuke to the class- and race-based meritocratic elitism of the selective four-year institutions and established an emphasis on open admissions, community service, and upward mobility in the postsecondary system.

With the knowledge economy firmly in the saddle by the 1980s, the community college began expanding its mission at both ends of the curriculum in response to market demands. Community colleges became major players in course and course-cluster-based shadow education and training 
system. The shadow system of nondegreed courses offers three kinds of value: courses and clusters of courses that provide basic skills which allow further learning on the job and in formal courses, provide transferable credits for further education, and provide immediate earnings returns and career mobility in labor markets.

In addition to the expansion of courses and course clusters with bitesized value, community colleges have expanded formal award and degree offerings. These colleges have reacted to the constant upward ratcheting in degree requirements in every occupation that results from the upskilling dynamic ultimately tied to globalization. As degree requirements increase, community colleges have begun offering bachelor's degrees and postgraduate certificates, especially in occupations and professions with strong ties to local labor markets such as education, health care, and information technology.

As the community college adapts to meet core mission goals of market responsiveness and upward mobility, its attachment to localism and open admissions comes into conflict. The simultaneous growth of the noncredit shadow curriculum, the postsecondary system, and the bachelor's degree is dawning as "the age of and" in community colleges: they must strive to be loyal to democratic and meritocratic values, to be both global and locally responsive, to be internally coherent and externally responsive, to be providers of occupational liberal arts and professional curricula, and to be governed by community-based university and corporate systems. The result is an increasingly complex identity, an effect typical of globally responsive institutions. Thus, while community colleges have adapted to new realities, financing systems have not. State funding has declined as a share of community college revenue.

Federal funding is still overwhelmingly based on individual student aid, making no adjustments for the varied cost structures of the community college missions. Overall decline in the relative value of public aid and one-size-fits-all cost structures dilutes the community colleges' ability to fund every mission, especially nondegreed learning targeted to the neediest students.

Absent new public money, the funding squeeze, especially in public community colleges, will only get worse because the current funding crisis in postsecondary education reflects structural as well as cyclical changes in public postsecondary funding. As the share of state budgets going to higher education has fallen off by 13 percent since 1990, the share going to Medicaid has increased by two-thirds and the share going to prisons has increased by one-third. And since the last recession in 2000, state budgets have gone from bad to worse, forcing dramatic tuition increases in public institutions. The 2008 recession has triggered a new downward spiral in public funding at the state level. The federal higher education budget is undergoing a similar squeeze as tax cuts combine with a shift in resources toward health care, social security, and national defense. 
As money gets tighter, the traditional upper-middle-class eighteen- to twenty-four-year-old student becomes the preferred client in postsecondary education. These students arrive with tuition in hand, are assembled on campus, sit in large classes scheduled during normal working hours, and are taught standardized academic curricula.

In these tough budgetary times, the least attractive student clients are the nontraditional students, especially those with work and family responsibilities.

Low-income adults and out-of-school youth need more financial aid than the traditional eighteen- to twenty-four-year-old student, and adult students are more expensive because they need to integrate their studies seamlessly with work and family needs. They require more expensive courses that mix applied and academic learning, flexible scheduling that increases personnel and facilities costs, and family services such as child care and counseling to hold it all together and plan for future transitions. The footloose and fancy-free traditional student can afford mistakes that adults with jobs and families cannot. Low-income adults also may require remedial or refresher courses that no one wants to pay for, along with customized workoriented courses that often need to be offered in bite-sized, nondegreed chunks which are not eligible for federal subsidies and are funded, and then only partly, by a minority of states.

The accountability movement continues to be bad news for nontraditional students who tend to concentrate in community colleges.

What makes matters even worse is that the increasing cost of higher education has inspired an accountability movement that may be good news for traditional students but continues to be bad news for nontraditional students. Accountability measures tend to focus on increasing degree attainment, reducing time to graduation, reducing dropouts and loan defaults, and funding only nonremedial degreed courses and higher standards for student learning outcomes. The problem for low-income adults is that the combined effect of reduced financial support and higher standards encourages colleges to cater to the most well-heeled and well-prepared young students who are least likely to be distracted by work and family.

\section{The worst-case scenario that confronts us is that the financial strains emerging in higher education will result in a gradual and silent aban- donment of working families and nontraditional students.}

In an economy where good jobs require postsecondary education and training, the growing economic divide between those with and those without postsecondary education and training will continue to widen, fostering intergenerational reproduction of economic and cultural elites inimical to our democratic ethos and our worthiness for leadership in the global contest of cultures. 


\section{References}

CPS Utilities. Current Population Survey, 1973-2007. Los Angeles: Unicon Research Corporation, Mar. 2007.

Kirsch, I. S., and Jungeblut, A. Profiling the Literacy Proficiencies of JTPA and ES/UI Populations. Princeton, N.J.: Educational Testing Service, 1992.

Kirsch, I. S., Jungeblut, A., Jenkins, L., and Kolstad, A. Adult Literacy in America. Washington, D.C.: U.S. Government Printing Office, 1993.

McKinsey and Company. The Emerging Global Market. Boston: McKinsey Global Institute, June 2005.

National Center for Education Statistics. National Education Longitudinal Study of 1988: Base-Year to Fourth Follow-up Data Files. Washington, D.C.: U.S. Department of Education, 1988.

National Center for Education Statistics. National Adult Literacy Survey. Washington, D.C.: U.S. Department of Education, 1992.

Steurer, S. J., Smith, L., and Tracy, A. Education Reduces Crime: Three-State Recidivism Study. Lanham, Md.: Correctional Education Association, 2001.

ANTHONY P. CARNEVALE is president and research professor at the Georgetown University Center on Education and the Workforce.

JEFF STROHL is a labor economist and is director of research at the Georgetown University Center on Education and the Workforce.

NiCOLE SMITH is a research professor at the Georgetown University Center on Education and the Workforce. 